\title{
Microarray identifies ADAM family members as key responders to TGF- $\beta I$ in alveolar epithelial cells
}

\author{
Dominic T Keating ${ }^{1,2}$, Denise M Sadlier ${ }^{1}$, Andrea Patricelli ${ }^{1}$, \\ Sinead M Smith ${ }^{3}$, Dermot Walls ${ }^{3}$, Jim J Egan ${ }^{2}$ and Peter P Doran*1
}

\begin{abstract}
Address: ${ }^{1}$ General Clinical Research Unit, Mater Misericordiae University Hospital, School of Medicine and Medical Sciences, University College Dublin, Dublin 7, Ireland, 2Advanced Lung Disease Programme and Lung Transplant Unit, Mater Misericordiae University Hospital and ${ }^{3}$ School of Biotechnology, Dublin City University, Dublin, Ireland

Email: Dominic T Keating - dkeating@mater.ie; Denise M Sadlier - dsadlier@partners.org; Andrea Patricelli - apatricelli@mater.ie; Sinead M Smith - smithsi@tcd.ie; Dermot Walls - dermot.walls@dcu.ie; Jim J Egan - jegan@mater.ie;

Peter P Doran* - pdoran.genome@mater.ie

* Corresponding author
\end{abstract}

Published: 01 September 2006

Respiratory Research 2006, 7:114 doi:10.1186/1465-9921-7-114
Received: 29 May 2006

Accepted: 0 I September 2006

This article is available from: http://respiratory-research.com/content/7/I/II4

(c) 2006 Keating et al; licensee BioMed Central Ltd.

This is an Open Access article distributed under the terms of the Creative Commons Attribution License (http://creativecommons.org/licenses/by/2.0), which permits unrestricted use, distribution, and reproduction in any medium, provided the original work is properly cited.

\begin{abstract}
The molecular mechanisms of Idiopathic Pulmonary Fibrosis (IPF) remain elusive. Transforming Growth Factor beta I (TGF- $\beta$ I) is a key effector cytokine in the development of lung fibrosis. We used microarray and computational biology strategies to identify genes whose expression is significantly altered in alveolar epithelial cells (A549) in response to TGF- $\beta$ I, IL-4 and IL-I 3 and Epstein Barr virus.

A549 cells were exposed to $10 \mathrm{ng} / \mathrm{ml} \mathrm{TGF-} \beta$ I, IL-4 and IL- 13 at serial time points. Total RNA was used for hybridisation to Affymetrix Human Genome UI33A microarrays. Each in vitro time-point was studied in duplicate and an average RMA value computed. Expression data for each time point was compared to control and a signal log ratio of 0.6 or greater taken to identify significant differential regulation. Using normalised RMA values and unsupervised Average Linkage Hierarchical Cluster Analysis, a list of 312 extracellular matrix (ECM) proteins or modulators of matrix turnover was curated via Onto-Compare and Gene-Ontology (GO) databases for baited cluster analysis of ECM associated genes.

Interrogation of the dataset using ontological classification focused cluster analysis revealed coordinate differential expression of a large cohort of extracellular matrix associated genes. Of this grouping members of the ADAM (A disintegrin and Metalloproteinase domain containing) family of genes were differentially expressed. ADAM gene expression was also identified in EBV infected A549 cells as well as IL-13 and IL-4 stimulated cells. We probed pathologenomic activities (activation and functional activity) of ADAMI 9 and ADAMTS9 using siRNA and collagen assays. Knockdown of these genes resulted in diminished production of collagen in A549 cells exposed to TGF- $\beta$ I, suggesting a potential role for these molecules in ECM accumulation in IPF.
\end{abstract}




\section{Background}

Idiopathic pulmonary fibrosis (IPF) is a progressive and lethal pulmonary fibrotic lung disease. It is the most common form of the idiopathic interstitial pneumonias and is unresponsive to treatment resulting in a median survival from diagnosis of 2.9 years [1]. Although the pathogenesis of IPF remains elusive, a number of conditions and risk factors are associated with the disease, including cigarette smoking, several viral proteins, and genetic predisposition to IPF [2].

During both lung development and fibrogenesis, mesenchymal signaling alters alveolar epithelial cell phenotype and regulates pneumocyte differentiation [3,4]. Effective cell function in both the epithelium and the mesenchyme is dependent on signals originating in both compartments, acting in a complimentary axis. In disease the unchecked signaling emanating from these compartments establishes persistent fibroblast migration and extracellular matrix deposition with resultant pulmonary fibro$\operatorname{sis}[5]$.

Injured alveolar epithelail cells release a number of profibrotic cytokines including transforming growth factorsbeta-1, platelet derived growth factor tumour necrosis factor-alpha and interleukin-1 [6]. As a result of these mediators being released there a chemoattraction gradient for fibroblasts toward these areas of lung, with subsequent phenotypic differentiation.

TGF- $\beta 1$ is a prominent mediator in normal wound repair without the development of fibrosis[8]. Excess production of latent TGF- $\beta 1$ and active TGF- $\beta 1$ has been associated with the development of temporary inflammation, however, only TGF- $\beta 1$ overexpression results in fibroblast migration and proliferation with increased deposition of extracellular matrix. This suggests that inflammation in IPF is not crucial for pathogenesis but may instead be an associated phenomenon [9].

Targeted overexpression of TGF- $\beta 1$ is associated with augmented fibrosis, while antagonism of the growth factor results in abrogation o the fibrotic process. TGF- $\beta 1$ knockout mice die prematurely due to developmental retardation and progressive inflammation[10]; however, treatment with TGF- $\beta 1$ specific antagonists in mice did not result in a significant disturbance of the immune system[11]. TGF- $\beta 1$ has been shown to augment epithelial cell apoptosis and inhibition of this process has been shown to reduce fibrosis in animal models[12,13]. In other studies instillation of apoptotic cells into inflamed lungs has accelerated healing in a TGF- $\beta 1$ dependent manner[14].
TGF- $\beta 1$ is consistently associated with progressive fibrosis with increased expression being associated with a variety of fibrotic lung disease [15-17]. Adenovirus-mediated gene transfer of TGF- $\beta 1$ resulted in severe fibrosis in animal models [15]; while $\alpha \mathrm{V} \beta 6$ integrin (a TGF- $\beta 1$ activator) knockout mice developed lung inflammation but not fibrosis in response to bleomycin[18]. TGF- $\beta 1$ displays a pivotal role in the development of a fibrotic process in animal models, however the reasons surrounding its overexpression and the predilection towards a fibrotic phenotype in this setting remains unexplained.

Interleukin (IL)-13, a Th2 cytokine, has been shown to be increased in IPF [19], while the lungs of mice injured with bleomycin display increased IL-13 and its receptor IL13Ralpha2 [20]. The vehicle for fibrosis in response to IL13 is activated TGF- $\beta 1$ [21]. In asthmatic individuals the overexpression of IL-13 is associated with subepithelial fibrosis which has obvious implications for the development of idiopathic fibrosis [22]. IL-4 is also increased in the lungs of IPF patients and in bleomycin murine models [23]. The role for IL-4 in IPF may be two fold, limiting Tcell migration and stimulating fibrosis. IL-4 transforms fibroblasts into myofibroblasts inferring a role in the fibrotic process [24]. Through the release of TGF- $\beta 2$ IL-4 initiates the release of matrix proteins by myofibroblasts while inhibition of its receptor in bleomycin-injured mice attenuates the fibrotic response $[20,22]$.

Epstein-Barr virus (EBV) is a ubiquitous human herpesvirus associated with various diseases including infectious mononucleosis, Burkitt's lymphoma and Hodgkin's disease. A link between EBV and IPF has been suggested since Vergnon and colleagues demonstrated an elevation in the IgA levels against viral capsid antigen in IPF patients [25]. EBV usually infects the upper respiratory tract but has also been shown to infect and replicate in the lower respiratory tract. Immunohistochemical studies suggest that this replication occurs in the type II alveolar epithelial cells [26]. Further evidence for EBV involvement in IPF comes from the observation of a poorer prognosis in these patients when associated with EBV latent membrane protein 1 (LMP1) in epithelial cells [27]. LMP1 is an EBV associated protein expressed on the surface of EBV Infected cells in the latent and replicating phase [28]. Aberrant DNA found in lung tissue and serum of IPF patients suggested a mechanism by which a persistent virus can change from a latent to a productive phase via recombinatorial events [29].

In this study we explore the multifactorial nature of epithelial cell injury in pulmonary fibrosis in response to potential fibrogenic stimuli. 


\section{Methods \\ Cell culture and EBV Infection in vitro}

Human alveolar epithelial cells (A549) were obtained from European Collection of Cell Cultures (Salisbury, United Kingdom) and grown in vitro in Hams F12 (Life Technologies, Paisley, Scotland) supplemented with 10\% fetal calf serum, $146 \mathrm{mg} / \mathrm{L} \mathrm{L}$-glutamine, $1 \%$ penicillin and $1 \%$ streptomycin. For stimulation experiments, cells were serum starved overnight before exposure to $10 \mathrm{ng} / \mathrm{ml} \mathrm{TGF}-$ $\beta 1$, IL-4 or IL-13 (Sigma) for the indicated time points, control samples were maintained in serum free conditions.

To effect virus infection, A549 cells were co-cultured with Akata cells (an Epstein-Barr virus-negative cell line infected with recombinant EBV carrying the neomycin resistance gene) [30]. The Akata cell line was maintained in RPMI 1640 (Life Technologies, Paisley, Scotland) supplemented with 10\% FBS, 2 mM L-glutamine, $100 \mathrm{U} / \mathrm{ml}$ Penicillin, $100 \mu \mathrm{g} / \mathrm{ml}$ streptomycin and $700 \mu \mathrm{g} / \mathrm{ml}$ G418. The viral lytic cycle was induced in the Akata cells by adding goat anti-human serum Immunoglobulin G (Sigma) at $100 \mu \mathrm{g} / \mathrm{ml}$. After four hours the Akata cells were added to the A549 wells at a concentration of $5 \times 10^{5} / \mathrm{ml}$. After two days incubation half the medium was replaced with medium containing 5\% FCS. Following a further 4 days incubation the media containing the Akata cells was removed, pelleted down and resuspended in M5 media (Calcium free DMEM supplemented with 5\% Horse Serum, $2 \mathrm{mM}$ glutamine, cortisol, $2 \mathrm{ng} / \mathrm{ml} \mathrm{EGF,} 10 \mathrm{mg} / \mathrm{ml}$ Insulin, $100 \mathrm{ng} / \mathrm{ml}$ cholera toxin, $100 \mathrm{U} / \mathrm{ml}$ Penicillin and $100 \mu \mathrm{g} / \mathrm{ml}$ streptomycin). $2 \mathrm{mls}$ of this cell suspension was then placed onto the wells and left to incubate for 2 days. The wells were washed with PBS and the media replaced with fresh medium containing 10\% FCS. Following incubation for 24 hours $700 \mathrm{ng} / \mathrm{ml}$ G418 (Sigma) was added to select for EBV-infected A549 cells.

\section{Western blot analysis}

Latent infection of the A549 cells with EBV was confirmed by the detection of latent membrane protein 1 (LMP1) by Western blot. After removal of EBV/A549 cells from flasks protein lysates were prepared by boiling for 10 minutes in 2\% SDS, $100 \mathrm{mM} \mathrm{NaCl}, 0.01 \mathrm{M}$ Tris-HCl, 5\% $\beta$-Mercaptoethanol, $1 \mathrm{mM}$ EDTA, $100 \mu \mathrm{g}$ of phenylmethylsulfonyl fluoride/ml, and $2 \mu \mathrm{g}$ of leupeptin/ml. The product was then sonicated on ice and clarified at room temperature by centrifugation at $12,000 \mathrm{rpm}$ for $10 \mathrm{~min}$. Protein fractionated by discontinuous SDS-5-10\% polyacrylamide gel electrophoresis and blotted onto a nitrocellulose filter. Anti-LMP1 CS1-4 antibody (University of Wales, Cardiff) cocktail diluted to $1: 100$ in Blotto (5\% skim milk and $0.1 \%$ Tween 20 in Tris-buffered saline) was used to probe the filters at $4{ }^{\circ} \mathrm{C}$ overnight. Alkaline phosphatase-conjugated sheep anti-mouse immunoglobulin G (IgG)
(Promega) was used to detect immunocomplexes, which were visualized using 5-bromo-4-chloro-3-indolylphosphate (BCIP)-nitroblue tetrazolium liquid substrate (Sigma).

\section{RNA extraction and gene array analysis}

Following stimulation of A549 cells with $10 \mathrm{ng} / \mathrm{ml}$ TGFB1 for 15 mins, 30 mins, 2 hour and 4 hours, RNA isolation, cDNA synthesis, in vitro transcription and microarray analysis were performed as previously reported [31] and in accordance with Affymetrix protocols(Affymetrix, Santa Clara, California). Arrays were scanned with a confocal scanner (Affymetrix). Each RNA sample derived from an individual well and $15 \mathrm{~min}, 30 \mathrm{~min}, 2$ hour and 4 hour in vitro exposures were microarrayed in duplicate on HU133 Affymetrix chips. Image files were obtained through Affymetrix GeneChip software (MAS5) and subsequently robust multichip analysis (RMA) was performed. To ensure the average was statistically significant a t-test and $\mathrm{p}$-value were generated. Only those genes with a p-value $\leq$ 0.01 were included in subsequent bioinformatic analysis. Expression data was further probed to identify those genes whose expression is altered. Expression data for each time point was compared to control and a signal log ratio of 0.6 or greater (equivalent to a fold change in expression of 1.5 or greater) was taken to identify significant differential regulation. Using normalised RMA values, unsupervised average linkage hierarchical cluster analysis was performed using an Eisen software program [32]. Cluster analysis is a group of mathematical techniques for the identification of patterns in large datasets. Briefly, a distance metric is used to calculate the similarity between the expression profiles of a group of genes. The more similar the expression profiles of genes are, the closer they are placed together on a dendrogram or tree. A list of 312 extracellular matrix proteins or modulators of matrix turnover was curated via the publicly available Onto-Compare and Gene-Ontology databases [33].

\section{Real-time PCR}

Reverse transcription was carried out using the Promega reverse transcription system. $1 \mu \mathrm{l}$ of Oligo(dT) ${ }_{15}(0.5 \mu \mathrm{g} /$ $\mu \mathrm{l})$ was mixed with $1 \mu \mathrm{g}$ of total RNA and the volume brought to $5 \mathrm{ml}$ with sterile nuclease-free water. The mixture was incubated at $70^{\circ} \mathrm{C}$ for $10 \mathrm{~min}$ and then placed on ice. Once cooled the following was added for a $20 \mu \mathrm{l}$ reaction: $2 \mu \mathrm{l} 10 \times$ transcription buffer, $0.5 \mu \mathrm{l}$ RNasin (40 units/ $\mu \mathrm{l}), 2 \mu \mathrm{l}$ dNTP mix (10 mM), $4 \mu \mathrm{lgCl}_{2}(25 \mathrm{mM})$, $1 \mu \mathrm{l}$ AVM-RT (Avian Myeloblastic Virus Reverse Transcriptase)(20 units/ $\mu \mathrm{l}$ ), and brought to a final volume of $20 \mu \mathrm{l}$ with nuclease free water. The sample was mixed by repeated pipetting and then centrifuged to collect the sample at the bottom of the PCR reaction tube. The mixture was incubated at $37^{\circ} \mathrm{C}$ for an hour and heated to $95^{\circ} \mathrm{C}$ for 
$2 \mathrm{~min}$ in order to inactivate the enzyme. The subsequent cDNA was stored at $4{ }^{\circ} \mathrm{C}$ until required.

Real time RT-PCR was performed on a TaqMan ABI 7700 Sequence Detection System ${ }^{\circledast}$ (AppliedBiosystems, Weiterstadt, Germany) using heat activated AmpliTaq Gold, DNA polymerase (Amplitaq Gold, Applied Biosystems, Weiterstadt, Germany) as previously described [34]. The ribosomal $18 \mathrm{~S}$ was used as an endogenous control for normalisation of the target genes. Its primer and probe were supplied as a PDAR (predeveloped assay reagent) from Applied Biosystems with the probe labelled with VIC at the $5^{\prime}$ end. Primer and probes for the genes of interest were designed in PrimerExpress ${ }^{\circledast}$ version 2.0(AppliedBiosystems). The probes for the target genes were labelled with fluorescent dye, FAM on the $5^{\prime}$ end and the quencher TAMRA onthe 3' end. PCR reactions were set up in separate tubes with TaqMan Universal PCR Master Mix from Applied Biosystems. Optimal concentration of primers and probes were $200 \mathrm{nM}$ for probe, $300 \mathrm{nM}$ for its primers, and $100 \mathrm{nM}$ reaction mix for PDARs. cDNA was amplified on the 7700HT detection system (Applied bioscience) at default thermal conditions: 2 min @ $50^{\circ} \mathrm{C}, 10$ min $@ 95^{\circ} \mathrm{C}$ for enzyme activation and the 40 cycles of 15 sec@95 ${ }^{\circ} \mathrm{C}$ for denaturation and 1 min @60 ${ }^{\circ} \mathrm{C}$ for annealing and extension. Controls consisting of distilled $\mathrm{H}_{2} \mathrm{O}$ were negative in all runs. All measurements were performed in triplicate for each time point.

Following cycling, to ensure specificity, melt curve analysis was carried out to verify the amplification of PCR products starting at $65^{\circ} \mathrm{C}$ and ramping to $90^{\circ} \mathrm{C}$ at $.1^{\circ} \mathrm{C} / \mathrm{sec}$. One peak in the melt curve indicated no secondary, nonspecific products were formed. All results were compared to those for unstimulated A549 cells and analysed using the delta delta Ct method. All experiments were performed in triplicate for each time point.

\section{Gene silencing by RNA interference}

Knock down of gene expression was achieved using RNA interference. Two siRNA duplexes were designed and synthesised for silencing ADAM19 and ADAMTS9. (Qiagen Inc. CA, USA). A chemically synthesized non-silencing siRNA duplex that had no known homology with mammalian genes was used to control for non-specific silencing events. $2 \times 10^{5} \mathrm{~A} 549$ cells were added to each well of a 6-well plate in $3 \mathrm{ml}$ growth media and incubated under the standard conditions of $37^{\circ} \mathrm{C}$ and $5 \% \mathrm{CO}_{2}$ in a humid incubator for $24 \mathrm{hr}$. A sufficient amount of growth medium was added to $5 \mu \mathrm{g}$ siRNA and $30 \mu \mathrm{l}$ RNAifect (Qiagen) to bring the final volume to $100 \mu$ l. Following incubation, media was removed from the cells and this mix was added drop-wise. $3 \mathrm{ml}$ growth medium was added and the cells were incubated for $48 \mathrm{hr}$ under standard conditions. Following this, all growth media was removed and cells were washed with sterile PBS. $1 \mathrm{ml}$ TRI$\mathrm{zol}^{\mathrm{TM}}$ (Sigma) was added to each well and left for $10 \mathrm{~min}$ at room temperature with occasional shaking. $200 \mu \mathrm{l}$ chloroform was added and the mixture was shaken, left at room temperature for $15 \mathrm{~min}$ and centrifuged at 13,000 g at $4{ }^{\circ} \mathrm{C}$ for $15 \mathrm{~min}$. The upper aqueous layer was transferred to a fresh $1.5 \mathrm{ml}$ tube. $0.5 \mathrm{ml}$ ice-cold isopropanol was added to the aqueous phase, shaken and left to stand on ice for $10 \mathrm{~min}$ before it was centrifuged at $13000 \mathrm{~g}$ at $4^{\circ} \mathrm{C}$ for $10 \mathrm{~min}$. The supernatant was removed and $1 \mathrm{ml}$ of sterile $75 \%$ ethanol was added to wash the pellet by gentle vortexing and centrifugation at $7500 \mathrm{~g}$ for $5 \mathrm{~min}$. The ethanol was removed and the pellet was allowed to air-dry for $5 \mathrm{~min}$. Pellets were resuspended in $50 \mu \mathrm{l} 0.1 \%$ DEPC treated $\mathrm{H}_{2} \mathrm{O}$ by heating at $60^{\circ} \mathrm{C}$ for $15 \mathrm{~min}$. All RNA was stored at $-80^{\circ} \mathrm{C}$.

\section{Collagen Assay}

Sircol collagen assay (Biocolour) was performed as per manufacturer's guidelines. The dye reagent contains sirius red in picric acid. Sirius Red is an anionic dye with sulphonic acid side chain groups. These groups react with the side chain groups of the basic amino acids present in collagen under specific conditions permitting determination of mammalian collagens types I to V. Briefly $100 \mu \mathrm{l}$ aliquots of cell culture supernatant were incubated with the dye reagent by gentle mixing for 30 mins at room temperature. The dye-bound collagen was pelleted by centrifugation at $10000 \mathrm{~g}$ for 10 mins. Unbound dye was removed by aspiration of the supernatant following centrifugation. The collagen dye complex was washed with $500 \mu \mathrm{l}$ ethanol to ensure complete removal of unbound dye. The collagen bound dye pellet was recovered by solubilization in an alkaline solution. Absorbance of bound collagen at $540 \mathrm{~nm}$ was determined using a spectrophotometer. Bound collagen concentration was determined by comparison with absorbance standard curve of known concentration samples.

\section{Results}

\section{Global changes in gene expression in response to TGF- $\beta$ I} Exposure of A549 alveolar epithelial cells to $10 \mathrm{ng} / \mathrm{ml}$ TGF- $\beta 1$ was associated with significant changes in gene expression. For all time points data was normalised using RMA express and an average expression measure for each time point used to identify alterations in gene expression. RMA normalised data was found to be comparable across the time series with the computed average expression aligning to the individual chip hybridisation boxplots (Figure 1, Panel A). Distinct temporal patterns of gene expression were observed throughout the time course exposure, with significant altered expression following 15 minutes exposure. The total number of genes altered was lower following 30 minutes with a sustained increase seen over the remaining time points. The same temporal pat- 
Panel A

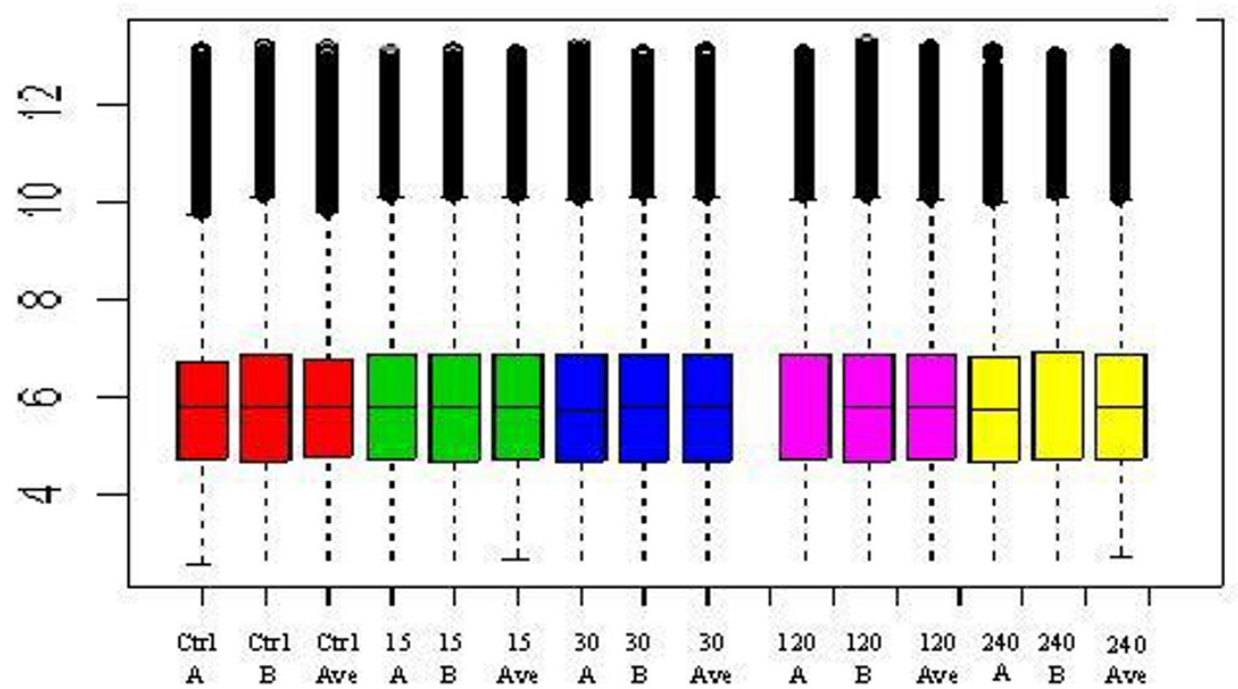

Panel B

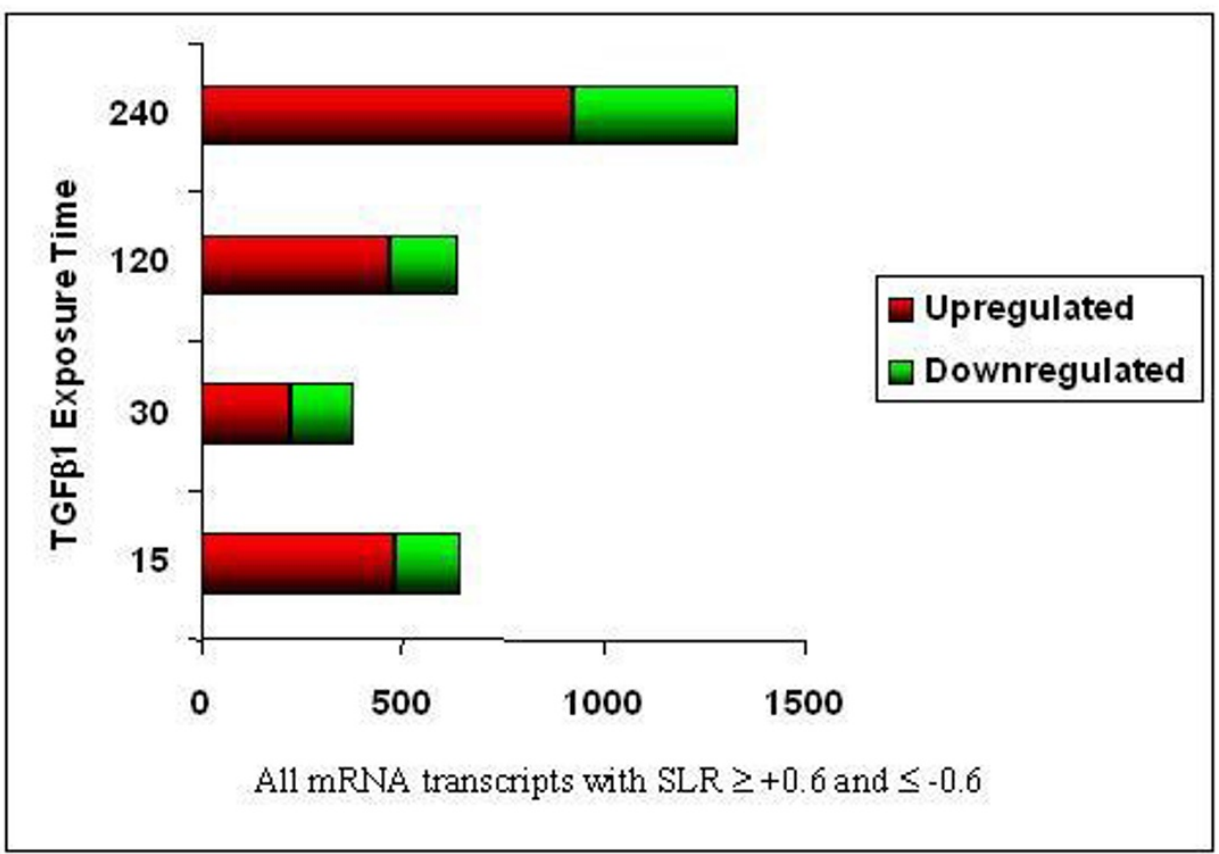

Figure I

Global changes in alveolar epithelial cell gene expression following exposure to I0 ng/ml TGF- $\beta$ I. Panel A shows a boxplot of normalised data and computed average arrays for each time point demonstrating comparability of the normalised data. Each array is performed in duplicate (A and $B$ ) and is shown beside their computed average (Ave). Arrays were performed for control (Ctrl), and TGF- $\beta$ I stimulation at I5, 30, I20, and 240 minutes. Panel B shows a summary of the observed alterations in gene expression at all the time points following TGF- $\beta$ I stimulation. Genes were defined as upregulated when signal log ratio $(S L R)>0.6$ and downregulated when $S L R<-0.6$. 
Table I: Genes undergoing most striking up-regulation at I5, 30, I20 and 240 minutes post TGF- $\beta$ I exposure.

\begin{tabular}{|c|c|c|}
\hline Accession & Gene & A549 Vs. 15 mins \\
\hline NM 001554 & Cysteine-rich, angiogenic inducer, 61 & 1.1 \\
\hline NM 006745 & Sterol-C4-methyl oxidase-like & 1.0 \\
\hline NM 004735 & Leucine rich repeat interacting protein I & 0.9 \\
\hline $\mathrm{AB} 023420$ & Heat shock 70KDa protein 4 & 0.8 \\
\hline NM 018063 & Helicase, lymphoid-specific & 0.8 \\
\hline NM 006621 & S-adenosylhomocysteine hydrolase-like I & 0.8 \\
\hline NM 006364 & Sec23 homolog A (S. cerevisiae) & 0.7 \\
\hline Accession & Gene & A549 Vs. 30 mins \\
\hline NM_003670 & $\begin{array}{l}\text { Basic helix-loop-helix domain containing, class } \\
\text { B, } 2\end{array}$ & 1.6 \\
\hline NM 002165 & Inhibitor of DNA binding I & 1.6 \\
\hline NM 002229 & Jun B proto-oncogene & 1.6 \\
\hline NM 005655 & TGFB inducible early growth factor & $\mathrm{I} .4$ \\
\hline NM 001554 & Cysteine-rich, angiogenic inducer, 61 & 1.2 \\
\hline NM 002228 & v-jun sarcoma virus 17 oncogene homolog & 1.2 \\
\hline NM 004907 & Immediate early protein & 1.1 \\
\hline Accession & Gene & A549 Vs. 120 mins \\
\hline NM 000602 & Serine proteinase inhibitor, clade $\mathrm{E}$ & 3.0 \\
\hline$\underline{\mathbf{S 6 9 7 3 8}}$ & Chemokine ligand 2 & 2.8 \\
\hline $\mathrm{AL574210}$ & Serine proteinase inhibitor, clade $E$ & 2.6 \\
\hline NM 002229 & Jun B proto-oncogene & 2.5 \\
\hline NM 004428 & Ephrin-AI & 2.3 \\
\hline NM 00064I & Interleukin II & 2.2 \\
\hline NM 003897 & Immediate early response 3 & 2.2 \\
\hline Accession & Gene & A549 Vs. 240 mins \\
\hline NM 000602 & Serine proteinase inhibitor, clade $E$ & 3.2 \\
\hline AL574210 & Serine proteinase inhibitor, clade $\mathrm{E}$ & 2.7 \\
\hline NM 001901 & Connective tissue growth factor & 2.7 \\
\hline$\underline{S 69738}$ & Chemokine ligand 2 & 2.7 \\
\hline NM 00064I & Interleukin II & 2.3 \\
\hline NM 003897 & Immediate early response 3 & 2.0 \\
\hline NM 016109 & Angiopoietin-like 4 & 1.9 \\
\hline
\end{tabular}

tern of gene expression alterations was observed for both up and down regulated transcripts. Of the 22,216 gene sequences represented on the Affymetrix HGU133A oligonucleotide microarray $2.9 \%$ (649) genes), $1.7 \%$ (383 genes), $2.89 \%$ (643 genes) and $6.01 \%$ (1339 genes) were significantly altered following 15 minutes, 30 minutes, 2 hour and 4 hour exposure to TGF- $\beta 1$ respectively (Figure 1 , Panel B). Tables 1 and 2 highlight the genes whose mRNA levels were most strikingly altered at 15, 30, 120 and 240 minutes post TGF- $\beta 1$ exposure.

\section{Baited Cluster analysis Identifies Extracellular Matrix} Associated Genes as major responders to TGF- $\beta$ I exposure Figure 2, panel A shows the result of unsupervised hierarchical cluster analysis of all alveolar epithelial cell genes whose expression is significantly altered in response to TGF- $\beta 1$. As can be seen groups of genes are found to cluster together depending on the kinetics of their altered expression. Having delineated the global transcriptomic response of alveolar epithelial cells to TGF- $\beta 1$, we categorized the significantly perturbed genes according to their biological function. This approach permits rapid annotation of large datasets for the identification of functional patterns of dysregulation. All significantly perturbed genes were used as input in classification searches. Figure 2 Panel B shows the overall pattern of regulation of key functional families throughout the time course exposure. All gene families studied were found to increase over time, reflecting the increased transcriptomic activity in the latter time points. 
Table 2: Genes undergoing most striking down-regulation at I5, 30, I 20 and 240 minutes post TGF- $\beta$ I exposure.

\begin{tabular}{|c|c|c|}
\hline Accession & Gene & A549 Vs. 15 mins \\
\hline$\underline{\times 7230}$ & Corticotropin releasing hormone receptor & -0.5 \\
\hline NM 014012 & RAS-like GTP-binding & -0.5 \\
\hline NM 018028 & Hypothetical protein FLJI02II & -0.5 \\
\hline AW003030 & Splicing factor $3 \mathrm{~b}$, subunit I & -0.5 \\
\hline$\underline{\mathrm{XM} 373433}$ & Hypothetical protein BC002926 & -0.5 \\
\hline NM 015638 & Transient receptor potential cation channel & -0.5 \\
\hline NM 020660 & Connexin-36 & -0.5 \\
\hline Accession & Gene & A549 Vs. 30 mins \\
\hline NM 005469 & Peroxisomal acyl-CoA thioesterase & -0.5 \\
\hline AL57I723 & SPRY domain-containing SOCS box protein SSB-3 & -0.5 \\
\hline N39314 & Mitochondrial carrier triple repeat I & -0.5 \\
\hline$\underline{x 02761}$ & Fibronectin I & -0.5 \\
\hline NM 022829 & Solute carrier family 13 & -0.5 \\
\hline AK026737 & Fibronectin I & -0.5 \\
\hline NM 020660 & Connexin-36 & -0.5 \\
\hline Accession & Gene & A549 Vs. 120 mins \\
\hline $\mathrm{ABO} 2305$ & Cyclin-dependent kinase 2 & -0.5 \\
\hline NM 001086 & Arylacetamide deacetylase & -0.5 \\
\hline NM 004083 & Methionine-tRNA synthetase & -0.5 \\
\hline NM 006933 & Mitochondrial ribosomal protein S6 & -0.5 \\
\hline NM 013453 & Sperm protein associated with the nucleus, $\mathrm{X}$-linked & -0.5 \\
\hline NM 020660 & Connexin-36 & -0.5 \\
\hline AK026737 & Fibronectin I & -0.5 \\
\hline Accession & Gene & A549 Vs. 240 mins \\
\hline NM 005345 & Heat shock $70 \mathrm{Kda}$ protein IA & -0.5 \\
\hline NM 014158 & Core I UDP-galactose & -0.5 \\
\hline NM 005203 & Collagen, type XIII, alpha I & -0.5 \\
\hline$\underline{\underline{003203}}$ & Peripheral myelin protein 22 & -0.5 \\
\hline$\overline{N M 001417}$ & Eukaryotic translation initiation factor $4 \mathrm{~B}$ & -0.5 \\
\hline NM 017960 & Hypothetical protein FLJ20808 & -0.5 \\
\hline $\mathrm{ABO} 2305$ & Cyclin-dependent kinase 2 & -0.5 \\
\hline
\end{tabular}

Of the 312 ECM genes displayed on the microarray 95 were significantly altered in this setting. Figure 3 illustrates the extracellular matrix associated genes whose expression was altered in response to TGF- $\beta 1$ including matrix proteins, such as members of the collagen family and growth factors known to be involved in matrix regulation, including connective tissue growth factor and transforming growth factor. Figure 3, Panel A and B show the expression patterns of up and downregulated transcripts respectively.

\section{TGF- $\beta$ I stimulation drives ADAM family gene expression in alveolar epithelial cells}

Of note with respect to the mechanisms of fibrotic lung injury was the finding of coordinate differential regulation of ADAM gene family members. We focused on four ADAM family members identified in the ECM cluster of our oligonucleotide microarrays. ADAM19 and ADAMTS9 were increased in response to TGF- $\beta 1$ exposure, whilst mRNA levels of ADAM 28 and ADAMTS 8 were reduced.

Microarray findings were validated using quantitative real time PCR. ADAM19 expression was significantly enhanced by 6 fold at 4 hours (figure 4, panel A). ADAMTS9 analysis showed an increase in response to TGF- $\beta 1$ exposure after 15 minutes and reaching a significantly elevated level of 2 fold at 4 hours (figure 4, panel B).

ADAMTS8 was identified as being downregulated in response to TGF- $\beta 1$. Real time quantitative PCR confirmed the TGF- $\beta 1$ responsiveness of this gene in alveolar epithelial cells at all but the 4 hour exposure time points, 
Panel A

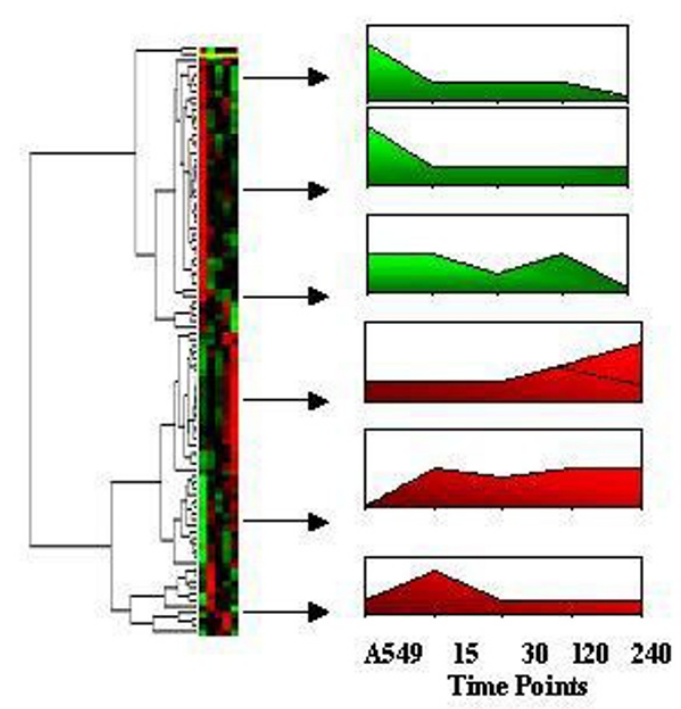

Panel B

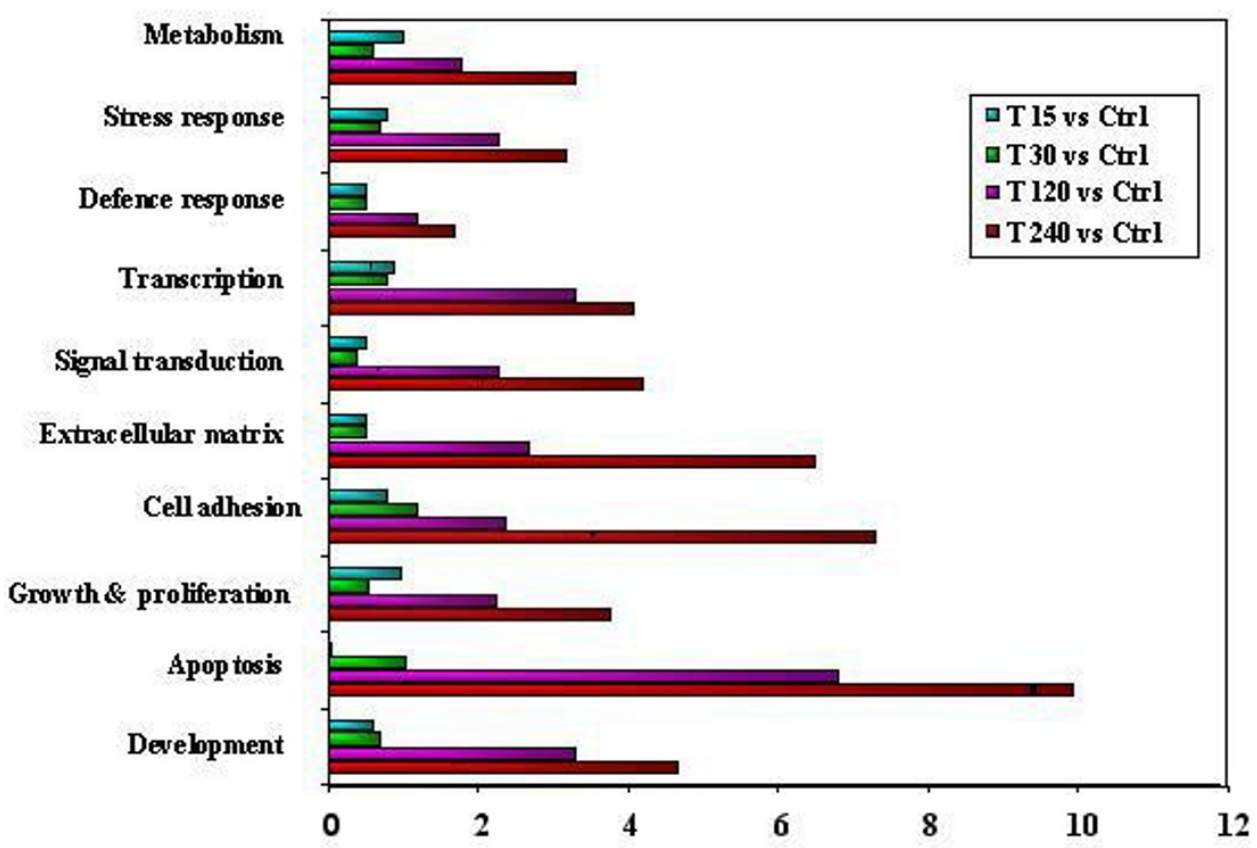

Percentage dysregulated mRN A transcrip ts

Figure 2

Functional classification of global gene expression changes in alveolar epithelial cells elicited by TGF- $\beta$ I. Panel A shows a cluster dendrogram of all arrays demonstrating aggregation of the data representative of each time point. Array image files were used as input to RMAExpress for normalization. In panel B all significantly dysregulated genes (SLR < - 0.6 \& SLR > $0.6)$ were used to classify the TGF- $\beta$ I induced transcriptome in terms of biological function of the perturbed genes. Shown is a bar chart describing the percentage of dysregulated transcripts, from each family found to be significantly changed at each time point. 
Panel A
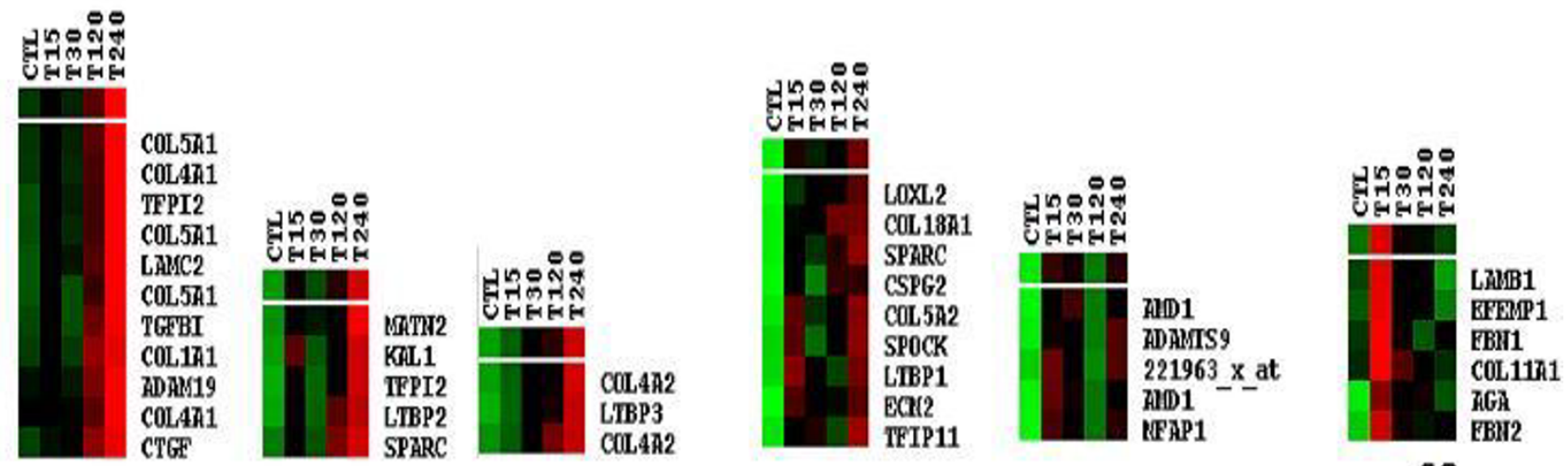

Panel B
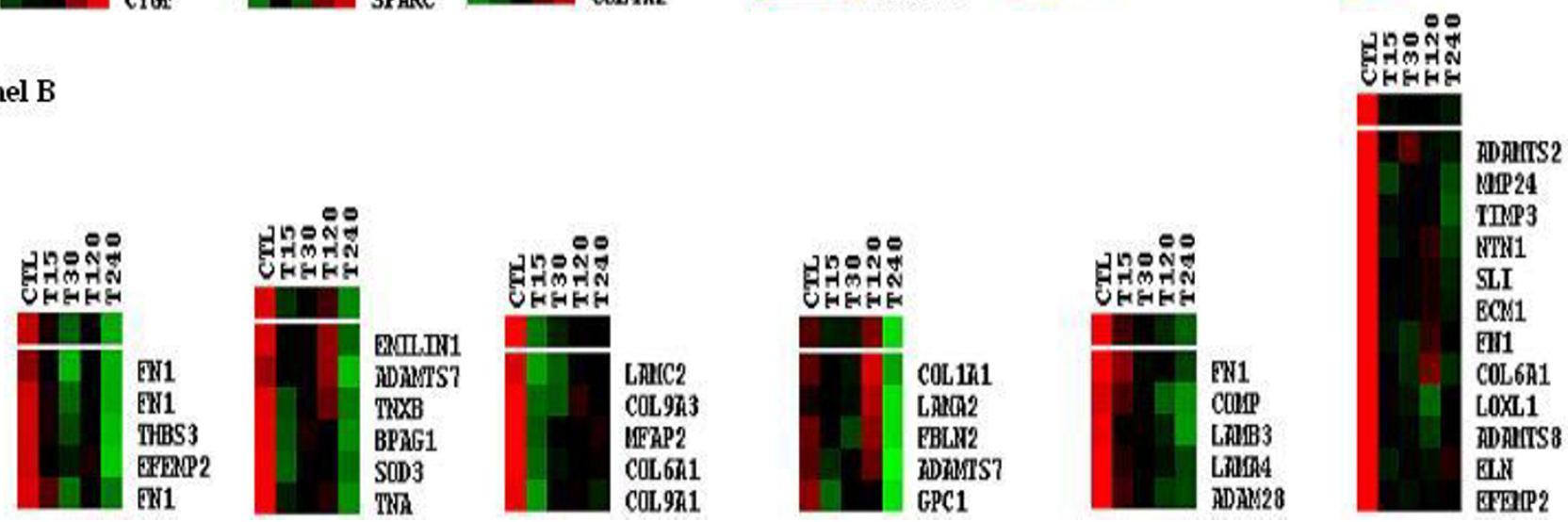

Figure 3

Extracellular matrix family gene expression in response to TGF- $\beta$ I. A list of 3 I 2 extracellular matrix associated genes obtained from Onto-Compare was used to scan for genes undergoing significant perturbation in TGF- $\beta$ I stimulated cells. Panel $A$ and $B$ illustrate ECM genes whose expression was found to increase and decrease respectively. Arrays shown in this figure are control (Ctl), TGF- $\beta$ I stimulated time points I5 min (TI5), 30 min (T30), I 20 min (TI20), and 240 min (T240).

(Figure 4, Panel C). Downregulation of ADAM 28 mRNA was confirmed by quantitative real-time PCR at 4 hours (Figure 4, Panel D).

These data confirm the microarray-identified alterations in ADAM family members in alveolar epithelial cells in response to TGF- $\beta 1$.

\section{mRNA levels of ADAM Family members are altered in response to endogenous and exogenous stimuli}

Having determined that exposure of alveolar epithelial cells to TGF- $\beta 1$ resulted in coordinate regulation of ADAM family members we explored the effect of other fibrotic stimuli on ADAM expression particularly IL-13 and IL-4.

Alveolar epithelial cells were exposed to $10 \mathrm{ng} / \mathrm{ml} \mathrm{IL-13}$ for 15, 30, 60, 120 and 240 mins and ADAM gene expression assessed by quantitative Real time PCR. Figure 5 Panel A and B demonstrates the induction of the TGF- $\beta 1$ upregulated genes, ADAM19 and ADAMTS9 in response to IL-13 stimulation. ADAM 19 was found to be significantly induced at the 60 min time point post IL-13 exposure, then the levels returning to almost baseline by 240 min. ADAMTS9 was significantly enhanced at all time points, with maximal induction seen in the 240 min setting. In contrast IL-13 was found to have little effect on the TGF- $\beta 1$ downregulated genes, ADAM28 and ADAMTS 8 (Figure 5, Panel C and D).

Interleukin 4 exposure had no significant effect on the expression of ADAM 19 or ADAMTS9. There was a general trend towards downregulation of these transcripts, the opposite effects to that seen with TGF- $\beta 1$. Suppression of the TGF- $\beta 1$ downregulated genes ADAM 28 and ADAMTS 8 by IL- 4 was interrogated by real time PCR. However only the latter time points of IL- 4 exposure produced a statistically significant change in ADAM 28 expression (Figure 6, panel C). 

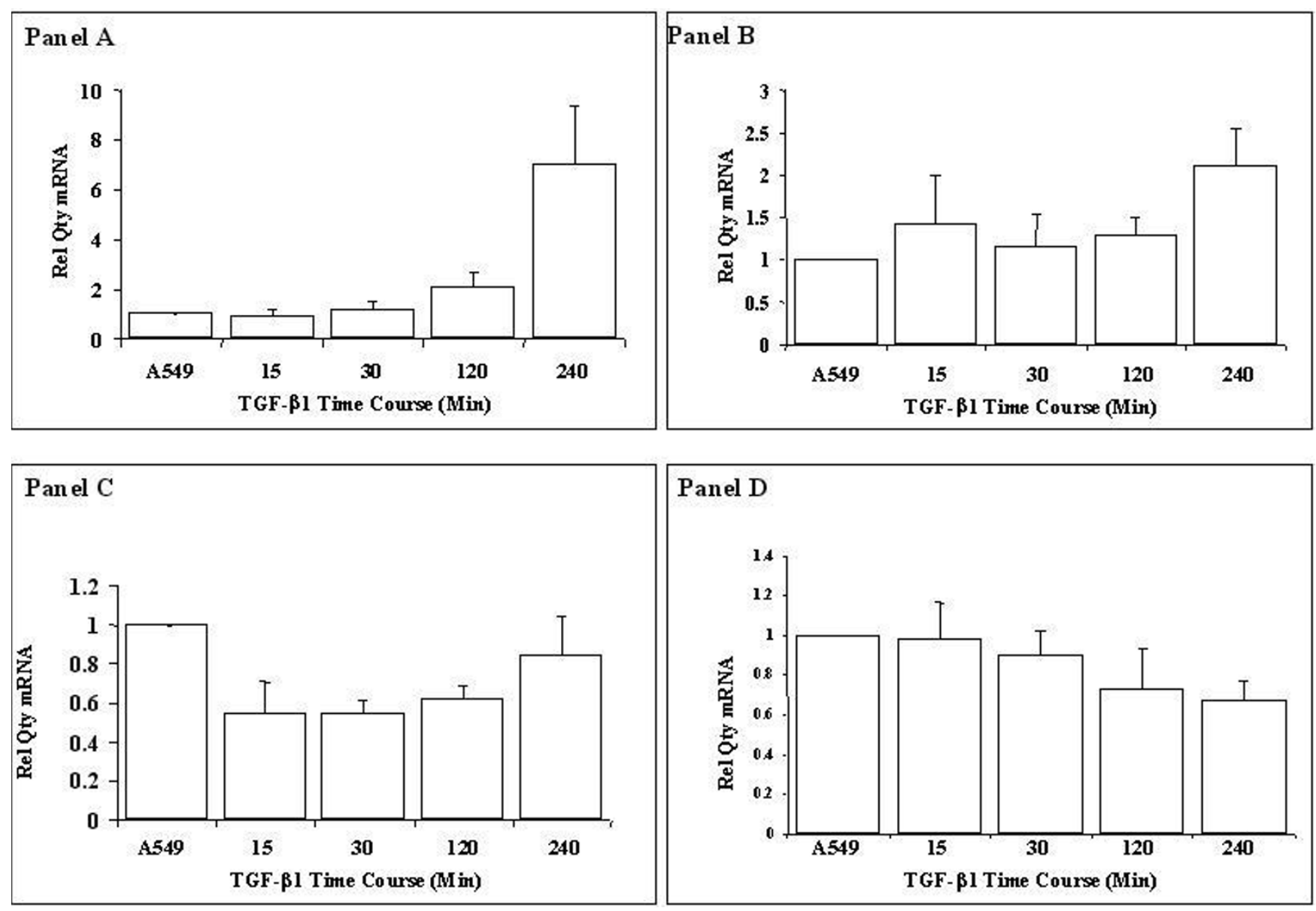

\section{Figure 4}

ADAM mRNA expression levels in TGF- $\beta$ I stimulated alveolar epithelial cells. Confirmation of the oligonucleotide microarray identified ADAM 19, ADAMTS9, ADAMTS8 and ADAM 28 (Panels A, B, C and D respectively.) by quantitative real time PCR. All expression values were normalised to GAPDH to control for equivalence of loading. Data are quoted relative to control, which has a value of $\mathrm{I}$.

EBV infection of A549 cells was confirmed by western blot expression of latent membrane protein 1 (LMP1) in A549 infected cells (Figure 7). Having confirmed the viral infection of A549 cells with EBV we determined the effect of this infection on ADAM gene expression. ADAM19 and ADAMTS9 were found to be significantly induced in virus infected alveolar epithelial cells. Stimulation of these infected cells with TGF- $\beta 1$ resulted in further enhanced expression of these genes, suggesting a synergistic activity of EBV and TGF- $\beta 1$ in the fibrotic lung (Figure 8, panel A and $\mathrm{B}$ ). Of note was the finding that EBV infection had no statistically significant effect on ADAM 28 gene expression either alone or in conjunction with TGF- $\beta 1$. Decreased expression of ADAMTS8 was found in virus infected TGF$\beta 1$ exposed alveolar epithelial cells (Figure 8, Panel C and D).

\section{ADAM 19 and ADAMTS9 Gene Silencing inhibits lung fibrosis in vitro}

To determine the biological importance of enhanced ADAM 19 and ADAMTS9 expression in response to TGF$\beta 1$ exposure we evaluated the effect of gene knock down on the cellular phenotype. To achieve this goal, specific small interfering RNA oligonucleotide [35] probes were designed and transfected into A549 alveolar epithelial cells using the lipofectamine strategy as described. Following transfection knockdown of the genes was confirmed by quantitative PCR (Figure 9, Panel A). Transfected cells were exposed to $10 \mathrm{ng} / \mathrm{ml}$ TGF- $\beta 1$ for four hours as previously described and collagen (Types I-V) deposition, as a hallmark of fibrosis, was determined using the Sircol assay kit. Figure 9 panel B demonstrates reduced collagen deposition in both ADAM 19 and ADAMTS9 siRNA trans- 

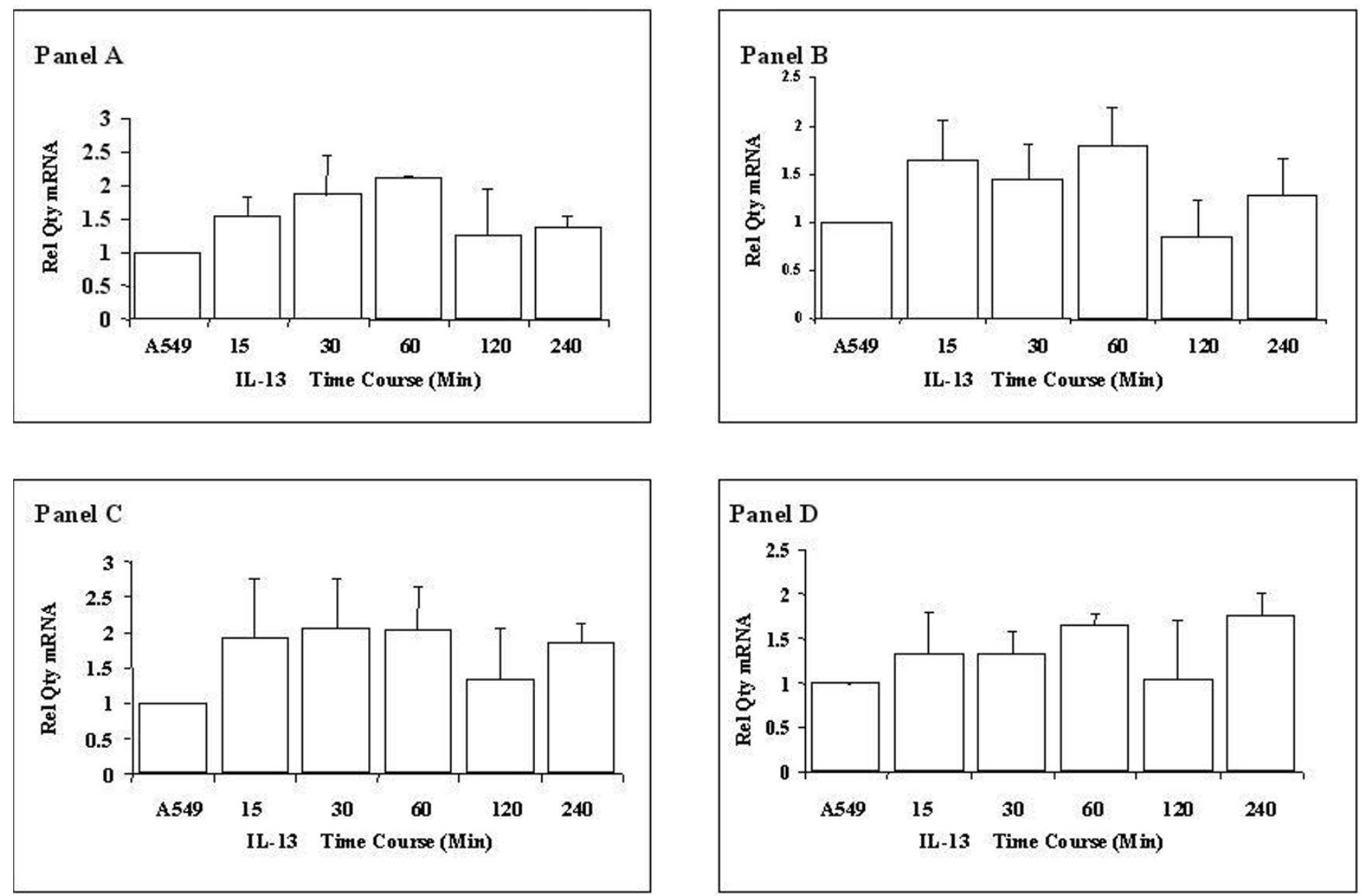

\section{Figure 5}

ADAM mRNA expression in response to interleukin- I3. A549 alveolar epithelial cells were exposed to $10 \mathrm{ng} / \mathrm{ml}$ Interleukin I3; mRNA expression of ADAM 19 (Panel A), ADAM 28 (Panel B), ADAMTS9 (Panel C) and ADAMTS8 (Panel D) quantified by Real Time PCR is shown. All expression values were normalised to GAPDH to control for equivalence of loading. Data are quoted relative to control, which has a value of $\mathrm{I}$.

fected cells. These data suggest that the upregulation of ADAM 19 and ADAMTS9 by TGF- $\beta 1$ in the setting of lung fibrosis plays a role in the deposition of collagen in the cellular milieu, thereby contributing to extracellular matrix deposition and lung scarring.

\section{Discussion}

To delineate the molecular events in the pathogenesis of pulmonary fibrosis we utilised an oligonucleotide microarray strategy to identify alveolar epithelial genes and gene clusters whose expression is altered in response to TGF- $\beta 1$. These studies identified a large number of genes whose expression was altered in a temporal fashion. Functional classification of the transcriptomic response identified coordinate expression of important functional groups of genes in response to TGF- $\beta 1$. Particular focus was made on genes that are associated with extracellular matrix and it's remodelling. We curated the Affymetrix Human Genome HU133a microarray to obtain a list of such genes represented on the chip. Approximately 30\% of this gene cohort was found to be differentially regulated further underpinning the relative contribution of matrix molecules and mediators to the response to TGF- $\beta 1$. Representative among these extracellular matrix genes were growth factors, collagens and members of the ADAM gene family. The interaction of epithelial cells with other local and infiltrating cell types drives the further articulation of the fibrotic response in the lung. The ability of ADAM family members to regulate the interaction of these cell types and indeed to regulate their interaction with the extracellular matrix raises the hypothesis that these mediators are important in driving the local fibrotic milieu in the lung.

The ADAM gene family encompasses the ADAM (A disintegrin and metalloproteinase domain containing protein) and ADAMTS (A disintegrin-like and metalloproteinase with thrombospondin type I motif) proteins. The ADAMTSs are soluble proteins that can bind to the ECM 

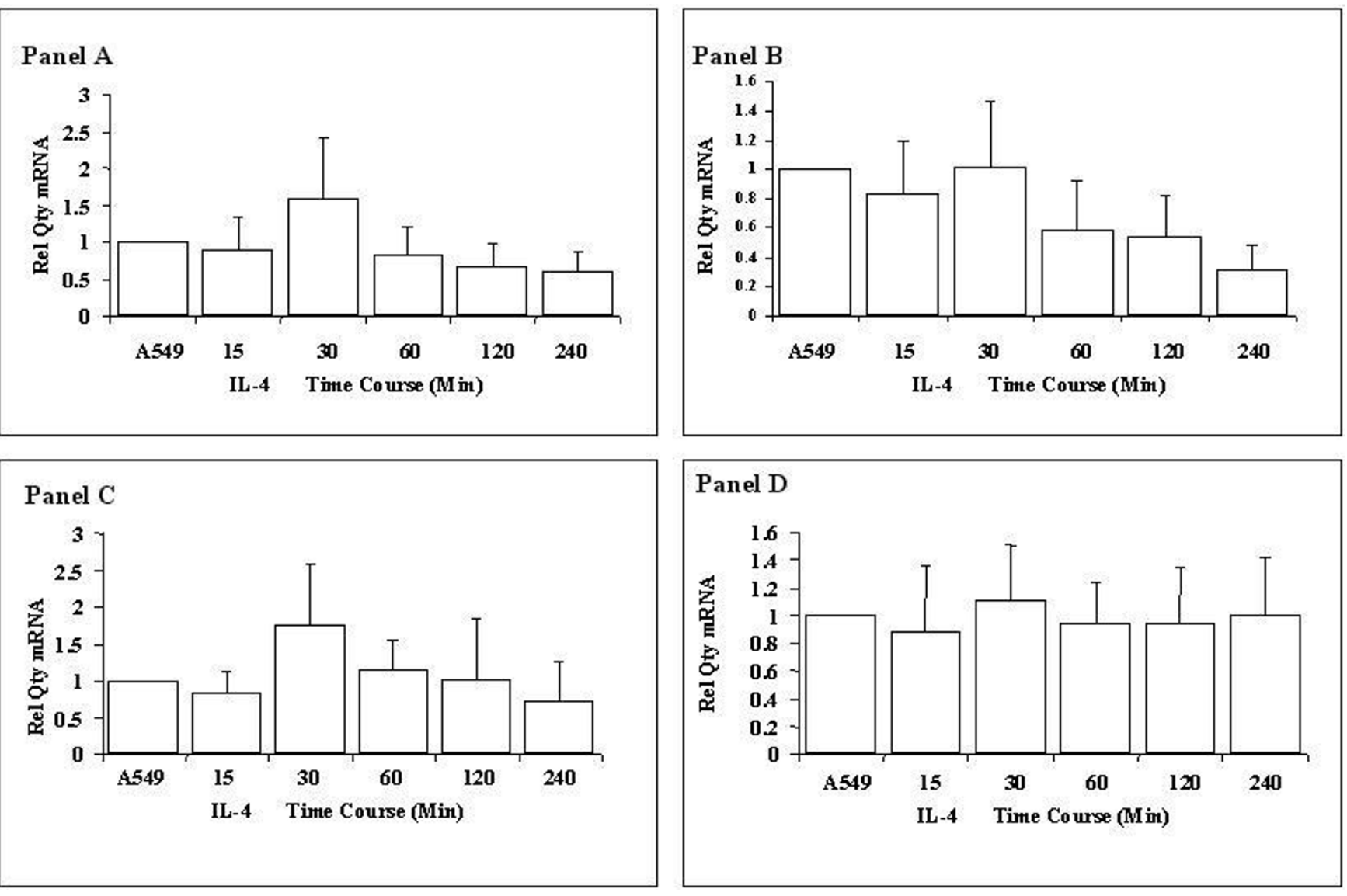

\section{Figure 6}

ADAM mRNA expression in response to interleukin-4. A549 alveolar epithelial cells were exposed to $10 \mathrm{ng} / \mathrm{ml} \mathrm{Inter}$ leukin 4. Shown are mRNA expressions of ADAM 19 (Panel A), ADAM 28 (Panel B), ADAMTS9 (Panel C) and ADAMTS8 (Panel D) quantified by Real Time PCR. All expression values were normalised to GAPDH to control for equivalence of loading. All measurements were completed in triplicate. Data are quoted relative to control, which has a value of $I$.

through the TS motifs. To date 34 members of the ADAMs family have been described, of which approximately $50 \%$ have been demonstrated to have protease activity. The substrates of ADAM protease activity are either integral membrane proteins or extracellular matrix proteins. In addition to their proteolytic activity, a number of ADAMs have been shown to bind integrins, via their disintegrin domain [36]. This dual activity of ADAMs suggests that these molecules are key mediators of biological processes such as cell-cell adhesion, ectodomain shedding, myoblast fusion and development. In the context of lung disease, this family is noteworthy. The possible role for ADAM family genes in lung fibrosis has been intimated by the observation that ADAM 10 autoantibody is associated with dermatomyositis related lung fibrosis and was shown to be present in one patient with IPF [37]. ADAM33 polymorphisms have also been shown to play a role in the development of asthma and also in disease progression via effects on airway remodelling [38].

The ADAM gene family is characterised by members that possess both proteolytic and cell-cell and cell-matrix interaction promoting activities. Thus the matrix proteolytic activities of ADAMs may represent an important facet of the development of pulmonary fibrosis, as their differential expression may alter the balance of matrix turnover. ADAM genes identified in this study have previously been associated with ventricular septal defects and valvular defects (ADAM19) [39], fibrotic eye disease (ADAMTS9) [40], disrupting angiogenesis (ADAMTS8) [41], and cell adhesion (ADAM 28) [42]. Functional assessment of the role of these genes in the setting of the lung was described using a gene knock down based strategy. These investigations showed an effect on collagen deposition in cells 


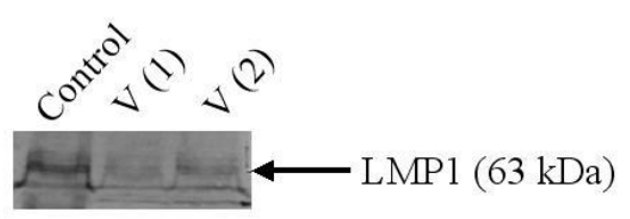

Figure 7

Epstein Barr Virus infection of alveolar epithelial cells. EBV infection of A549 alveolar epithelial cells was confirmed by western blotting for the viral protein LMPI. LMPI was detected in Akata cells (Control) as a positive control. Lanes VI and V2 demonstrate LMP-I protein expression in infected A549 alveolar epithelial cells. Each lane represents protein taken from separate experiments containing $4 \times 10^{5}$ cells.
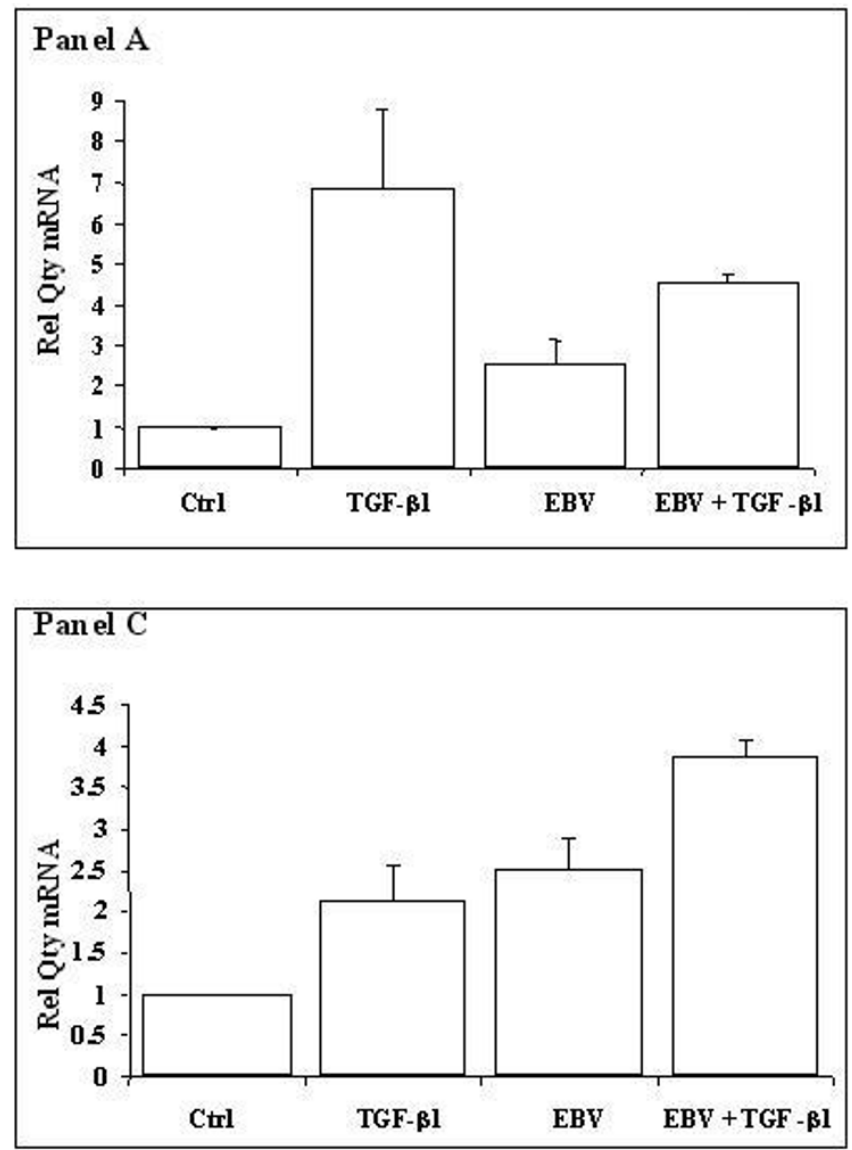

where the ADAM gene was knocked down, thus illustrating the importance of dysregulation of this gene family in the setting of lung fibrosis.

Having demonstrated the responsiveness and functional activity of ADAM family members in response to TGF- $\beta 1$ we explored their induction in response to other endogenous and exogenous pro-fibrotic insults. We determined the effect of IL-4 and IL-13 on alveolar epithelial cell ADAM production. Whilst the specific dysregulation of ADAM family members by these cytokines was different to that elicited by TGF- $\beta 1$, the general trend of ADAM response remained the same. These data suggest that the ADAM family response may be more indicative of the overall fibrotic activity rather than being a stimulus specific effect. These findings lend further weight to the argu-
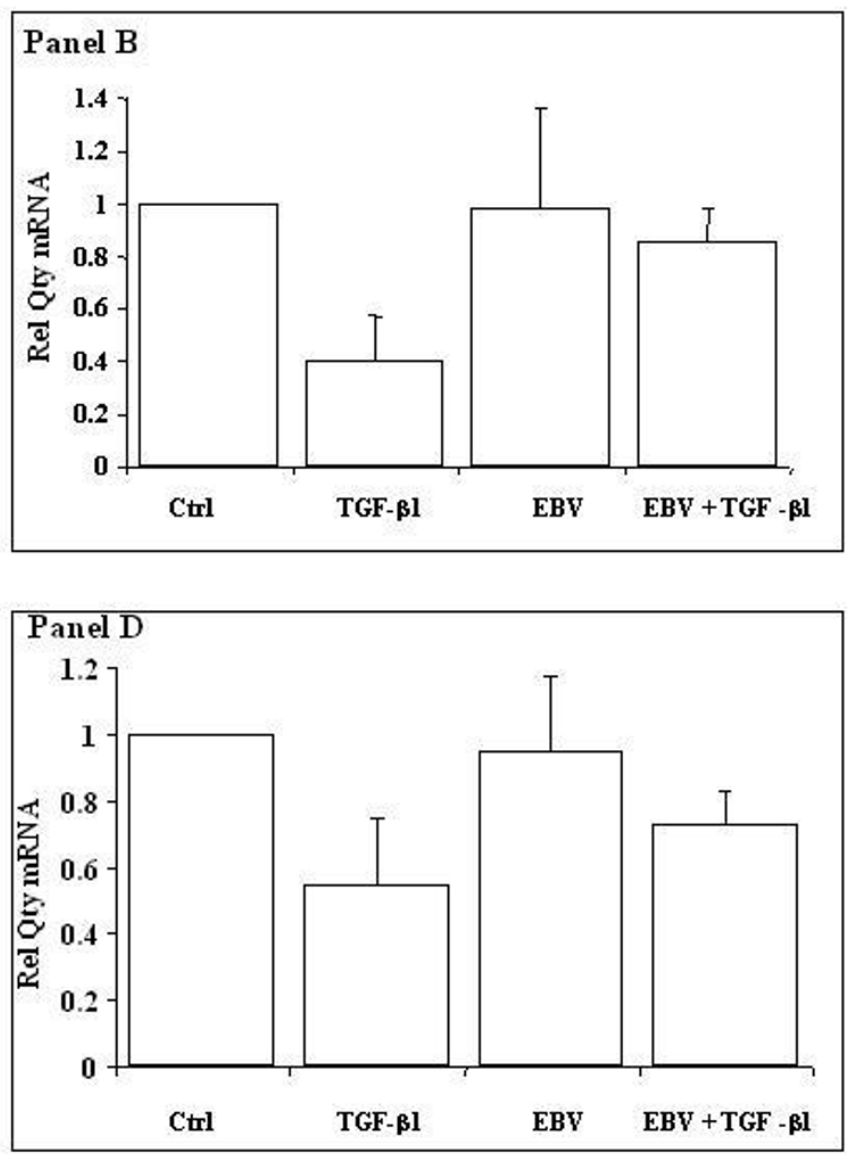

\section{Figure 8}

ADAM mRNA expression levels in Epstein Barr Virus infected alveolar epithelial cells. Using real time PCR the effect of EBV infection and TGF- $\beta$ I costimulation on ADAM expression was determined. ADAM expression in A549 cells (C), A549 cells stimulated with TGF- $\beta$ I (TGF), EBV infected A549 cells with (VTGF) and without (V) TGF- $\beta$ I are shown. Expression levels of ADAM 19 (Panel A), ADAM 28 (Panel B), ADAMTS9 (Panel C) and ADAMTS8 (Panel D) are shown. All expression values were normalised to $18 \mathrm{~S}$ rRNA to control for equivalence of loading. All measurements were completed in triplicate. Data are quoted relative to control, which has a value of $\mathrm{I}$. 

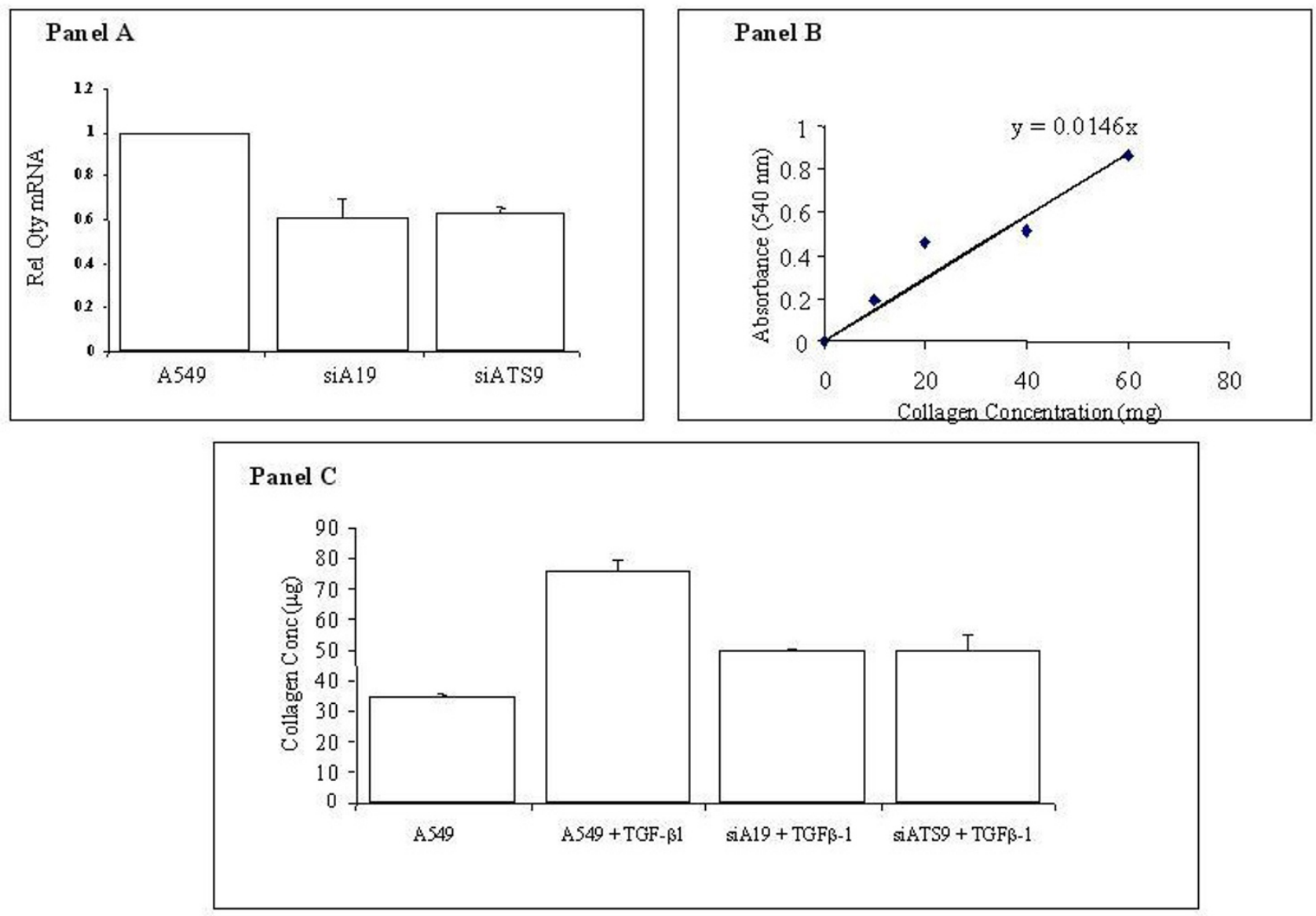

\section{Figure 9}

ADAM I 9 and ADAMTS9 gene knockdown abrogate TGF- $\beta I$ induced collaged production. Successful knockdown of ADAMI 9 and ADAMTS9 mRNA levels are shown in panel $A$ using real time PCR. In panel $B$ a standard curve for quantification is shown along with a bar chart illustrating reduced collagen deposition in response to TGF- $\beta$ I in ADAMI 9 and ADAMTS9 knockdown alveolar epithelial cells, respectively. All measurements were completed in triplicate.

ment that ADAM genes are central in mediating fibrosis as opposed to being an artefact of the experimental model.

Of particular note was the finding that viral infection itself resulted in ADAM family dysregulation in these cells, an effect that was further enhanced in experiments where repeated injury consisting of both EBV infection and TGF$\beta 1$ exposure induced ADAM gene expression. Whilst the ADAM gene expression was not as great in EBV infected cells as it was in A549 cells stimulated with TGF- $\beta 1$, a significant rise in ADAM19 and ADAMTS9 expression was observed. The combined stimulation of A549 cells with both EBV and TGF- $\beta 1$ resulted in an additional increase in ADAM19 and ADAMTS9 expression.

These data strengthen the hypothesis that the initiation and progression of lung fibrosis is due to injury of the epithelial cell with abnormal healing. Repetitive injury due to EBV infection is one plausible mediator for the devel- opment of fibrosis. It is of note that the ADAM response was consistently observed following different experimental exposures, underpinning the fact that these observed changes in ADAM expression and functionality may be of clinical importance and are not merely representative of experimental and model derived artefacts.

The data highlight the complex mechanism underpinning the initiation and progression of IPF and underline mechanisms for both the multifactorial nature of disease initiation and the mediators of deposition of extracellular matrix.

\section{References}

I. American Thoracic Society/European Respiratory Society International Multidisciplinary Consensus Classification of the Idiopathic Interstitial Pneumonias. This joint statement of the American Thoracic Society (ATS), and the European Respiratory Society (ERS) was adopted by the ATS board of directors, June $200 \mathrm{I}$ and by the ERS Executive Committee, June 2001. Am J Respir Crit Care Med 2002, 165(2):277-304. 
2. Crystal RG, Bitterman PB, Mossman B, Schwarz MI, Sheppard D, Almasy L, Chapman HA, Friedman SL, King TE Jr, Leinwand LA, et al:: Future research directions in idiopathic pulmonary fibrosis: summary of a National Heart, Lung, and Blood Institute working group. Am J Respir Crit Care Med 2002, I 66(2):236-246.

3. Warburton D, Zhao J, Berberich MA, Bernfield M: Molecular embryology of the lung: then, now, and in the future. $A m$ J Physiol 1999, 276(5 Pt I):L697-704.

4. Woodcock-Mitchell JL, Burkhardt AL, Mitchell JJ, Rannels SR, Rannels DE, Chiu JF, Low RB: Keratin species in type II pneumocytes in culture and during lung injury. Am Rev Respir Dis 1986, |34(3):566-57|.

5. Selman M, King TE, Pardo A: Idiopathic pulmonary fibrosis: prevailing and evolving hypotheses about its pathogenesis and implications for therapy. Ann Intern Med 200I, I34(2): I36-I5I.

6. Noble PW, Homer RJ: Idiopathic pulmonary fibrosis: new insights into pathogenesis. Clin Chest Med 2004, 25(4):749-758. vii

7. Ramos C, Montano M, Garcia-Alvarez J, Ruiz V, Uhal BD, Selman M, Pardo A: Fibroblasts from idiopathic pulmonary fibrosis and normal lungs differ in growth rate, apoptosis, and tissue inhibitor of metalloproteinases expression. Am J Respir Cell Mol Biol 200I, 24(5):59I-598.

8. Letterio JJ, Roberts AB: Transforming growth factor-beta I-deficient mice: identification of isoform-specific activities in vivo. J Leukoc Biol 1996, 59(6):769-774.

9. Xu YD, Hua J, Mui A, O'Connor R, Grotendorst G, Khalil N: Release of biologically active TGF-betal by alveolar epithelial cells results in pulmonary fibrosis. Am J Physiol Lung Cell Mol Physiol 2003, 285(3):L527-539.

10. Kulkarni AB, Huh CG, Becker D, Geiser A, Lyght M, Flanders KC, Roberts $A B$, Sporn MB, Ward JM, Karlsson S: Transforming growth factor beta I null mutation in mice causes excessive inflammatory response and early death. Proc Natl Acad Sci USA 1993, 90(2):770-774.

II. Yang YA, Dukhanina O, Tang B, Mamura M, Letterio J], MacGregor J, Patel SC, Khozin S, Liu ZY, Green J, et al.: Lifetime exposure to a soluble TGF-beta antagonist protects mice against metastasis without adverse side effects. J Clin Invest 2002, 109(12):1607-1615

12. Kuwano K, Kunitake R, Maeyama T, Hagimoto N, Kawasaki M, Matsuba T, Yoshimi M, Inoshima I, Yoshida K, Hara N: Attenuation of bleomycin-induced pneumopathy in mice by a caspase inhibitor. Am J Physiol Lung Cell Mol Physiol 200I, 280(2):L3I6-325.

13. Kuwano K, Hagimoto N, Kawasaki M, Yatomi T, Nakamura N, Nagata $\mathrm{S}$, Suda T, Kunitake R, Maeyama T, Miyazaki H, et al.: Essential roles of the Fas-Fas ligand pathway in the development of pulmonary fibrosis. I Clin Invest 1999, I 04(I): 13-19.

14. Huynh ML, Fadok VA, Henson PM: Phosphatidylserine-dependent ingestion of apoptotic cells promotes TGF-betal secretion and the resolution of inflammation. J Clin Invest 2002, I09(I):4I-50.

15. Sime PJ, Xing Z, Graham FL, Csaky KG, Gauldie J: Adenovectormediated gene transfer of active transforming growth factor-betal induces prolonged severe fibrosis in rat lung. J Clin Invest 1997, I00(4):768-776.

16. Giri SN, Hyde DM, Hollinger MA: Effect of antibody to transforming growth factor beta on bleomycin induced accumulation of lung collagen in mice. Thorax 1993, 48( I0):959-966.

17. Corrin B, Butcher D, McAnulty BJ, Dubois RM, Black CM, Laurent GJ, Harrison NK: Immunohistochemical localization of transforming growth factor-beta $I$ in the lungs of patients with systemic sclerosis, cryptogenic fibrosing alveolitis and other lung disorders. Histopathology 1994, 24(2): | 45-I50.

18. Munger JS, Huang X, Kawakatsu H, Griffiths MJ, Dalton SL, Wu J, Pittet JF, Kaminski N, Garat C, Matthay MA, et al.: The integrin alpha $v$ beta 6 binds and activates latent TGF beta I: a mechanism for regulating pulmonary inflammation and fibrosis. Cell 1999, 96(3):319-328.

19. Hancock A, Armstrong L, Gama R, Millar A: Production of interleukin 13 by alveolar macrophages from normal and fibrotic lung. Am J Respir Cell Mol Biol I998, I 8( ( ):60-65.

20. Jakubzick C, Choi ES, Joshi BH, Keane MP, Kunkel SL, Puri RK, Hogaboam CM: Therapeutic attenuation of pulmonary fibrosis via targeting of IL-4- and IL-I3-responsive cells. J Immunol 2003, I 7 I(5):2684-2693.
21. Lee CG, Homer RJ, Zhu Z, Lanone S, Wang X, Koteliansky V, Shipley JM, Gotwals $P$, Noble $P$, Chen $Q$, et al.: Interleukin- 13 induces tissue fibrosis by selectively stimulating and activating transforming growth factor beta(I). J Exp Med 200I, 194(6):809-82I.

22. Richter A, Puddicombe SM, Lordan JL, Bucchieri F, Wilson SJ, Djukanovic R, Dent G, Holgate ST, Davies DE: The contribution of interleukin (IL)-4 and IL-I3 to the epithelial-mesenchymal trophic unit in asthma. Am J Respir Cell Mol Biol 200I, 25(3):385-39I.

23. Ando M, Miyazaki E, Fukami T, Kumamoto T, Tsuda T: Interleukin4-producing cells in idiopathic pulmonary fibrosis: an immunohistochemical study. Respirology 1999, 4(4):383-391.

24. Saito A, Okazaki H, Sugawara I, Yamamoto K, Takizawa H: Potential action of IL-4 and IL- 13 as fibrogenic factors on lung fibroblasts in vitro. Int Arch Allergy Immunol 2003, I32(2): 168-176.

25. Vergnon JM, Vincent M, de The G, Mornex JF, Weynants P, Brune J: Cryptogenic fibrosing alveolitis and Epstein-Barr virus: an association? Lancet 1984, 2(8406):768-771.

26. Lung ML, Lam WK, So SY, Lam WP, Chan KH, Ng MH: Evidence that respiratory tract is major reservoir for Epstein-Barr virus. Lancet 1985, I (8434):889-892.

27. Tsukamoto K, Hayakawa H, Sato A, Chida K, Nakamura H, Miura K: Involvement of Epstein-Barr virus latent membrane protein $I$ in disease progression in patients with idiopathic pulmonary fibrosis. Thorax 2000, 55(II):958-96I.

28. Liebowitz D, Wang D, Kieff E: Orientation and patching of the latent infection membrane protein encoded by Epstein-Barr virus. J Virol I 986, 58(I):233-237.

29. Kelly BG, Lok SS, Hasleton PS, Egan JJ, Stewart JP: A rearranged form of Epstein-Barr virus DNA is associated with idiopathic pulmonary fibrosis. Am J Respir Crit Care Med 2002, 166(4):510-513.

30. Takada K, Horinouchi K, Ono Y, Aya T, Osato T, Takahashi M, Hayasaka S: An Epstein-Barr virus-producer line Akata: establishment of the cell line and analysis of viral DNA. Virus Genes 1991, 5(2): $147-156$

31. Sadlier DM, Connolly SB, Kieran NE, Roxburgh S, Brazil DP, Kairaitis L, Wang Y, Harris DC, Doran P, Brady HR: Sequential extracellular matrix-focused and baited-global cluster analysis of serial transcriptomic profiles identifies candidate modulators of renal tubulointerstitial fibrosis in murine adriamycininduced nephropathy. J Biol Chem 2004, 279(28):29670-29680.

32. Irizarry RA, Bolstad BM, Collin F, Cope LM, Hobbs B, Speed TP: Summaries of Affymetrix GeneChip probe level data. Nucleic Acids Res 2003, 3 I(4):el5.

33. Draghici S, Khatri P, Bhavsar P, Shah A, Krawetz SA, Tainsky MA: Onto-Tools, the toolkit of the modern biologist: OntoExpress, Onto-Compare, Onto-Design and Onto-Translate. Nucleic Acids Res 2003, 3 I (13):3775-378I.

34. Fink L, Seeger W, Ermert L, Hanze J, Stahl U, Grimminger F, Kummer W, Bohle RM: Real-time quantitative RT-PCR after laserassisted cell picking. Nat Med 1998, 4(I I): 1329-1333.

35. Parkes JG, Liu Y, Sirna JB, Templeton DM: Changes in gene expression with iron loading and chelation in cardiac myocytes and non-myocytic fibroblasts. J Mol Cell Cardiol 2000, 32(2):233-246.

36. White JM: ADAMs: modulators of cell-cell and cell-matrix interactions. Curr Opin Cell Biol 2003, I 5(5):598-606.

37. Fujita J, Takeuchi T, Dobashi N, Ohtsuki Y, Tokuda M, Takahara J: Detection of anti-ADAM 10 antibody in serum of a patient with pulmonary fibrosis associated with dermatomyositis. Ann Rheum Dis 1999, 58(1 2):770-772.

38. Jongepier H, Boezen HM, Dijkstra A, Howard TD, Vonk JM, Koppelman GH, Zheng SL, Meyers DA, Bleecker ER, Postma DS: Polymorphisms of the ADAM 33 gene are associated with accelerated lung function decline in asthma. Clin Exp Allergy 2004, 34(5):757-760.

39. Zhou HM, Weskamp G, Chesneau V, Sahin U, Vortkamp A, Horiuchi $\mathrm{K}$, Chiusaroli R, Hahn R, Wilkes D, Fisher P, et al.: Essential role for ADAMI 9 in cardiovascular morphogenesis. Mol Cell Biol 2004, 24(I):96-104

40. Bevitt DJ, Mohamed J, Catterall JB, Li Z, Arris CE, Hiscott P, Sheridan C, Langton KP, Barker MD, Clarke MP, et al.: Expression of ADAMTS metalloproteinases in the retinal pigment epithelium derived cell line ARPE- I9: transcriptional regulation by TNFalpha. Biochim Biophys Acta 2003, 1626(I-3):83-91. 
4I. Vazquez F, Hastings G, Ortega MA, Lane TF, Oikemus S, Lombardo M, Iruela-Arispe ML: METH-I, a human ortholog of ADAMTS$\mathrm{I}$, and METH-2 are members of a new family of proteins with angio-inhibitory activity. J Biol Chem I999, 274(33):23349-23357.

42. Bridges LC, Tani PH, Hanson KR, Roberts CM, Judkins MB, Bowditch RD: The lymphocyte metalloprotease MDC-L (ADAM 28) is a ligand for the integrin alpha4betal. J Biol Chem 2002, 277(5):3784-3792.

Publish with Bio Med Central and every scientist can read your work free of charge

"BioMed Central will be the most significant development for disseminating the results of biomedical research in our lifetime. " Sir Paul Nurse, Cancer Research UK

Your research papers will be:

- available free of charge to the entire biomedical community

- peer reviewed and published immediately upon acceptance

- cited in PubMed and archived on PubMed Central

- yours - you keep the copyright

Submit your manuscript here:

http://www.biomedcentral.com/info/publishing_adv.asp
BioMedcentral 